\title{
PERANCANGAN SISTEM PERAMALAN CUACA BERBASIS LOGIKA FUZZY
}

\author{
Ema Sastri Puspita, Liza Yulianti \\ Program Studi Teknik Informatika Fakultas Ilmu Komputer Universitas Dehasen Bengkulu \\ Jl. Meranti Raya No. 32 Kota Bengkulu 38228 Telp. (0736) 22027, 26957 Fax. (0736) 341139
}

\section{ABSTRACT}

This study aims to Implement Sugeno Fuzzy Logic method for weather forecasts and testing the accuracy of this research. The problem definition covers only the Data-Based Design of Weather Forecasting Sugeno Fuzzy Logic method using Matlab so as not to come out of the issues raised, it is used as the input is temperature, humidity and wind. In determining the results of research is an important weather forecasting particularly determined membership functions and the rule is used. Fuzzy logic using Sugeno method is best used in forecasting for the accuracy above $60 \%$. The more variables that are used as input it will produce better output (inaccurate).

Keywords: Weather Forecasting, Fuzzy Logic

\section{INTISARI}

Penelitian ini bertujuan untuk Menerapkan Logika Fuzzy Metode Sugeno untuk prakiraan cuaca dan melakukan pengujianakurasi dari penelitiaan ini. Adapun batasan masalah hanya mencakuppada Data Perancangan Peramalan Cuaca Berbasis Logika Fuzzy Metode Sugeno dengan menggunakan Matlab supaya tidak keluar dari permasalahan yang diangkat, maka yang dijadikan input adalahsuhu, kelembabandanangin Hasil penelitian adalah dalam menentukan sebuah peramalan khususnya cuaca yang penting ditentukan adalah fungsi keanggotaan dan rule yang digunakan. Logika Fuzzy dengan menggunakan metode sugeno sangat baik di gunakan dalam peramalan karena tingkat keakuratan diatas $60 \%$. Semakin banyak variabel-variabel yang dijadikan input maka akan menghasilkan output yang semakin baik (akurat).

Kata Kunci: Peramalan Cuaca, Logika Fuzzy

\section{PENDAHULUAN}

Dewasa ini perkembangan dunia komputer sudah begitu pesat. sehingga dalam berbagai proses kegiatan selalu kita jumpai keberadaanya.Pola iklim dan cuaca akhir-akhir ini sangat extrim.dengan keadaan cuaca seperti ini dapat merugikan bayak masyarakat.akhir-akhir ini sering terjadi hujan lebat dan mengakibatkan banjir Selama ini komputer dapat dipakai untuk membantu orang-orang dalam memecahkan problem. Semakin cerdas sistem itu dan semakin ditingkatkan level penanganan informasinya, maka semakin aktif peranan yang dilakukan oleh komputer. Dan selama ini terjadinya peningkatan minat dalam menggunakan komputer. Beberapa tugas tertentu membutuhkan pengetahuan yang sangat khusus, Komputer dengan tiga keunggulannya, yaitu kecepatan, keakurasian, serta ketidak jenuhan dapat diperbantukan langsung sebagai alat ataupun media yang sangat meringankan tugas seseorang.

Teknik kecerdasan yang paling populer sekarang ini.dapat diartikan sebagai sebuah perangkat lunak komputer yang memiliki basis pengetahuan untuk domain tertentu dan menggunakan penalaran inferensi menyerupai seorang pakar dalam memecahkan suatu masalah. Dimana bila dikaitkan dengan Manusia didalam peramalan cuaca atau memprediksi cuaca hari ini, dapat diciptakan suatu sistem komputer yang bertugas untuk mengetahui dan menganalisa gejala-gejala cuaca yang ada pada hari ini sehingga Stasuin Metrologi Fatmawati dapat memberitahukan bahwa prediksi cuaca hari ini bagaimana, Gejala yang disebabkan cuaca yang penulis maksudkan khusus Cuaca, dimana didalamnya terdiri dari banyak macam dan variasi gejala yang ditemui perkiraan cuaca.

Atas dasar uraian diatas, maka penulis dalam hal ini ingin membahas mengenai bagaimana caranya membuat suatu produk sistem yang dapat dengan mudah kita dapat memprediksi cuaca hari ini.

\section{TINJAUAN PUSTAKA}

\section{A) Konsep Cuaca}

Cuaca adalah kaadaan udara pada saat tertentu dan diwilaya tertentu yang relatif sempit dan dalam jangka waktu yang singkat. Unsur-unsur yang mempengaruhi cuaca dan iklim adalah:

1) Suhu udara perubahan suhu udara di satu tempat dengan tempat lainnya bergantung pada ketinggian tempat dan letak astronomisnya (lintang). Perubahan suhu karena perbedaan ketinggian jauh lebih cepat daripada perubahan suhu karena perbedaan letak lintang. Biasanya, perubahan suhu terjadi berkisar 0,6 derajat celcius tiap kenaikan $100 \mathrm{~m}$, alat ukur adalah Termometer. 
2) Tekanan udara tekanan udara adalah berat massa udara pada suatu wilayah. Tekanan udara menunjukkan tenaga yang bekerja untuk menggerakkan massa udara dalam setiap satuan luas tertentu. Tekanan udara semakin rendah jika semakin tinggi dari permukaan laut,alat ukur adalah Barometer.

3) Angin: angin adalah massa udara yang bergerak dari suatu tempat ke tempat lain. Tiupan angin terjadi jika di suatu daerah terdapat perbedaan tekanan udara, yaitu tekanan udara maksimum dan minumum. Angin bergerak dari daerah bertekanan udara maksimum ke minimum,alat ukur adalah Anenometer.

4) Kelembaban udara : kelembaban udara adalah kandungan uap air dalam udara. Uap air yang ada dalam udara berasal dari hasil penguapan air di permukaan bumi, air tanah, atau air yang berasal dari penguapan tumbuh-tumbuhan,alat ukur adalah Higrometer.

\section{B) Pengertian Suhu}

Dalam kehidupan sehari-hari, masyarakat umumnya untuk mengukur suhu cenderung menggunakan indera peraba, tetapi dengan adanya perkembangan teknologi, maka diciptakanlah termometer sebagai alat pengukur suhu yang akurat (valid). Pada abad 17 terdapat 30 jenis skala suhu yang membuat para ilmuan kebingungan untuk menentukan alat ukur suhu mana yang dapat digunakan secara universal dan diakui secara ilmiah. Hal ini memberikan inspirasi pada Anders Celcius (1701- 1744) sehingga pada tahun 1742 dia memperkenalkan skala yang digunakan sebagai pedoman pengukuran suhu. Skala ini diberi nama sesuai dengan namanya yaitu Skala Celcius.

Apabila benda didinginkan secara terus-menerus maka suhunya akan semakin dingin dan partikelnya akan berhenti bergerak, kondisi ini disebut kondisi nol mutlak. Pada fenomena ini, skala Celcius tidak bisa menjawab permasalahan ini maka Lord Kelvin (1842 - 1907) menawarkan skala baru yang diberi nama Kelvin. Skala Kelvin dimulai dari 273 K ketika air membeku dan $373 \mathrm{~K}$ ketika air mendidih. Sehingga nol mutlak sama dengan $0 \mathrm{~K}$ atau $-273^{\circ} \mathrm{C}$. Secara umum suhu didefinisikan sebagai besaran yang menyatakan derajat panas dingin suatu benda dan alat yang digunakan untuk mengukur suhu adalah thermometer.

Suhu diukur menggunakan termometer yang didasarkan pada bermacam jenis skala suhu. Seluruh dunia (kecuali Amerika Serikat) menggunakan skala Celsius untuk kebanyakan penggunaan pengukuran suhu. Dalam bidang ilmu pengetahuan, seluruh dunia mengukur suhu dalam kelvin pada skala suhu (mutlak) termodinamik dan juga dalam Celsius. Hanya di Amerika Serikat dan Jamaika saja, orang kebanyakan menggunakan skala Fahrenheit untuk tujuan-tujuan pengukuran suhu biasa (industri, prakiraan cuaca, dan kerajaan). Dan dalam bidangbidang teknologi khususnya, di Amerika Serikat, skala Rankine digunakan terutamanya dalam disiplindisiplin yang berkaitan dengan termodinamik seperti system pembakaran dan lain-lain.

Skala Celsius adalah suatu skala suhu yang didesain supaya titik beku air berada pada 0 derajat dan titik didih pada 100 derajat di tekanan atmosferik standar. Skala ini mendapat namanya dari ahli astronomi Anders Celsius (1701-1744), yang pertama kali mengusulkannya pada tahun 1742 .

\section{C) Pengertian Kelembaban Udara}

Menurut Gunawan (2011:22) Kelembaban adalah kandungan total uap air di udara atau banyaknya kandungan uap air di atmosfer. Udara atmosfer adalah campuran dari udara kering dan uap air. Kelembaban udara menggambarkan kandungan uap air di udara yang dapat dinyatakan sebagai kelembaban mutlak.

Secara umum kelembaban (Relative Humidity) adalah istilah yang digunakan untuk menggambarkan jumlah uap air yang ada di udara dan dinyatakan dalam persen dari jumlah uap air maksimum dalam kondisi jenuh.

\section{D) Pengertian Angin}

Secara singkat dapat dijelaskan bahwa angin adalah udara yang bergerak. Menurut Buys Ballot, ahli ilmu cuaca dari Perancis, angin adalah massa udara yang bergerak dari daerah bertekanan maksimum ke daerah bertekanan minimum. Gerakan massa udara yang arahnya horizontal dikenal dengan istilah angin. Anemometer mangkok adalah alat yang digunakan untuk mengukur kecepatan angin. Satuan yang biasa digunakan dalam menentukan kecepatan angin adalah $\mathrm{km} / \mathrm{jam}$ atau $\mathrm{knot}(1 \mathrm{knot}=0,5148 \mathrm{~m} / \mathrm{det}$ $=1,854 \mathrm{~km} / \mathrm{jam}$ ).

\section{E) Logika Fuzzy}

Logika fuzzy adalah sesuatu yang amat rumit dan tidak menyenangkan. Namun, sekali seseorang mulai mengenalnya, ia pasti akan sangat tertarik dan akan menjadi pendatang baru untuk ikut serta mempelajari logika fuzzy. Logika fuzzy dikatakan sebagai logika baru yang lama, sebab ilmu tentang logika fuzzy modern dan metodis baru ditemukan beberapa tahun 
yang lalu, padahal sebenarnya konsep tentang logika fuzzy itu sendiri sudah ada pada diri kita sejak lama.

Logika fuzzy adalah suatu cara yang tepat untuk memetakan suatu ruang input ke dalam suatu ruang output. Sebagai contoh:

1) Manajer pergudangan mengatakan pada manajer produksi seberapa banyak persediaan barang pada akhir minggu ini, kemudian manajer produksi akan menetapkan jumlah barang yang harus diproduksi esok hari.

2) Pelayan restoran memberikan pelayanan terhadap tamu, kemudian tamu akan memberikan tip yang sesuai atas baik tidaknya pelayan yang diberikan;

3) Anda mengatakan pada saya seberapa sejuk ruangan yang anda inginkan, saya akan mengatur putaran kipas yang ada pada ruangan ini.

4) Penumpang taksi berkata pada sopir taksi seberapa cepat laju kendaraan yang diinginkan, sopir taksi akan mengatur pijakan gas taksinya.

Menurut Asus Naba, logika fuzzy adalah: "Sebuah metodologi berhitung dengan variabel kata-kata (linguistic variable) sebagai pengganti berhitung dengan bilangan. Kata-kata digunakan dalam fuzzy logic memang tidak sepresisi bilangan, namun katakata jauh lebih dekat dengan intuisi manusia" [NAB2009]. Mengenai logika fuzzy pada dasarnya tidak semua keputusan dijelaskan dengan 0 atau 1, namun ada kondisi diantara keduanya, daerah diantara keduanya inilah yang disebut dengan fuzzy atau tersamar. Secara umum ada beberapa konsep sistem logika fuzzy, sebagai berikut dibawah ini:

Himpunan tegas yang merupakan nilai keanggotaan suatu item dalam suatu himpunan tertentu. Himpunan fuzzy yang merupakan suatu himpunana yang digunakan untuk mengatasi kekakuan dari himpunan tegas. Fungsi keanggotaan yang memiliki interval 0 sampai 1 Variabel linguistic yang merupakan suatu variabel yang memiliki nilai berupa kata-kata yang dinyatakan dalam bahasa alamiah dan bukan angka.

Operasi dasar himpunan fuzzy merupakan operasi untuk menggabungkan dan atau memodifikasi himpunan fuzzy, Aturan (rule) if-then fuzzy merupakan suatu pernyataan if-then, dimana beberapa kata-kata dalam pernyataan tersebut ditentukan oleh fungsi keanggotaan. Dalam proses pemanfaatan logika fuzzy, ada beberapa hal yang harus diperhatikan salah satunya adalah cara mengolah input menjadi output melalui sistem inferensi fuzzy. Metode inferensi fuzzy atau cara merumuskan pemetaan, dari masukan yang diberikan kepada sebuah keluaran. Proses ini melibatkan fungsi keanggotaan, operasi logika, serta aturan IF-THEN. Hasil dari proses ini akan menghasilkan sebuah sistem yang disebut dengan FIS (Fuzzy Inferensi System). Dalam logika fuzzy tersedia beberapa jenis FIS diantaranya adalah Mamdani, Sugeno, dan Tsukamoto.

\section{F) Himpunan Fuzzy}

Ada beberapa hal yang perlu diketahui dalam memahami sistem fuzzy, yaitu:

1) Variabel fuzzy

Variabel fuzzy merupakan variabel yang hendak dibahas dalam suatu sistem fuzzy. Contoh: umur, temperatur, permintaan, dsb.

2) Himpunan fuzzy

Himpunan fuzzy merupakan suatu grup yang mewakili suatu kondisi atau keadaan tertentu dalam suatu variabel fuzzy.

Sebagai contoh, variabel temperatur, terbagi menjadi 5 himpunan fuzzy, yaitu: DINGIN, SEJUK, NORMAL, HANGAT, dan PANAS.

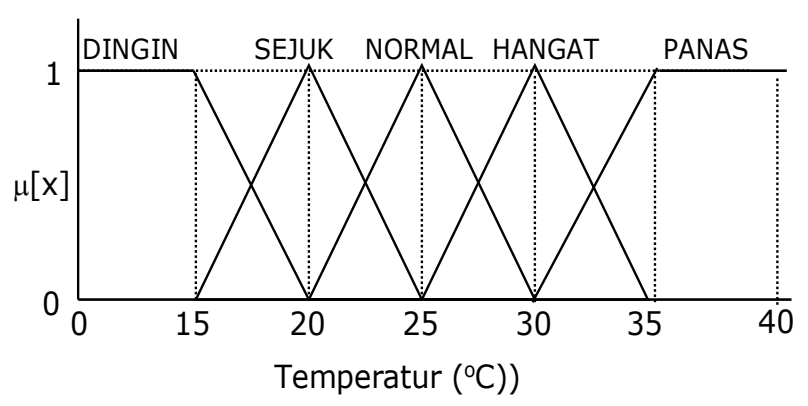

Gambar 1. Himpunan fuzzy pada variabel temperatur

\section{3) Semesta Pembicaraan}

Semesta pembicaraan adalah keseluruhan nilai yang diperbolehkan untuk dioperasikan dalam suatu variabel fuzzy. Semesta pembicaraan merupakan himpunan bilangan real yang senantiasa naik (bertambah) secara monoton dari kiri ke kanan. Nilai semesta pembicaraan dapat berupa bilangan positif maupun negatif. Adakalanya nilai semesta pembicaraan ini tidak dibatasi batas atasnya.

\section{4) Domain}

Domain himpunan fuzzy adalah keseluruhan nilai yang diijinkan dalam semesta pembicaraan dan boleh dioperasikan dalam suatu himpunan fuzzy. Seperti halnya semesta pembicaraan, domain merupakan himpunan bilangan real yang senantiasa naik (bertambah) secara monoton dari kiri ke kanan. Nilai domain dapat berupa bilangan positif maupun negatif. Perolehan Data beserta rentang nilai. Sebagian data diatas dipergunakan sebagai variabel masukan. 
Tabel 1. Klasifikasi Variabel

\begin{tabular}{|l|l|}
\hline Kreteria & Keterangan \\
\hline Tekanan & $\begin{array}{l}<145=\text { Konektivitas lemah } \\
145 \text { to } 205=\text { Konektivitas kuat } \\
>205=\text { Konektivitas sangat kuat }\end{array}$ \\
\hline Suhu Udara & $\begin{array}{l}<1000=\text { Energinya kecil } \\
1000-2500=\text { Energinya besar } \\
>2500=\text { Energinya sangat besar }\end{array}$ \\
\hline Kelembaban & $\begin{array}{l}<10=\text { Kandungan uap air sedikit } \\
\text { Udara }\end{array}$ \\
& $>60$ to $60=$ Kandungan uap air sedang \\
&
\end{tabular}

\section{Pembentukan Fungsi Keanggotan}

Penelitian diawali dengan cara :

a) Pengelompokan masing-masing variabel dengan masing-masing himpunan memiliki rentang nilai tertentu.

b) Nilai keanggotaan ( $\alpha$-predikat) dilakukan dengan mengambil nilai minimum karena menggunakan operator AND

c) Kurva untuk daerah tepi berbentuk bahu, sedangkan bagian tengah berbentuk segitiga. Untuk menentukan prakiraan cuaca umum, diperlukan kombinasi kriteria dari 3 variabel seperti pada gambar. Untuk mendapatkan keluaran, caranya dengan menghitung rata-rata terbobot berdasarkan rumus

\section{Pembentukan Fungsi Keanggotaan}

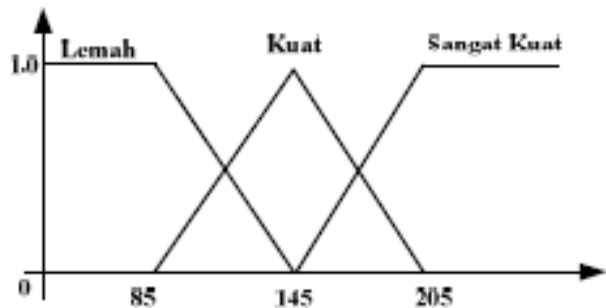

Gambar 2. Fungsi Keanggotaan Variabel Tekanan Udara

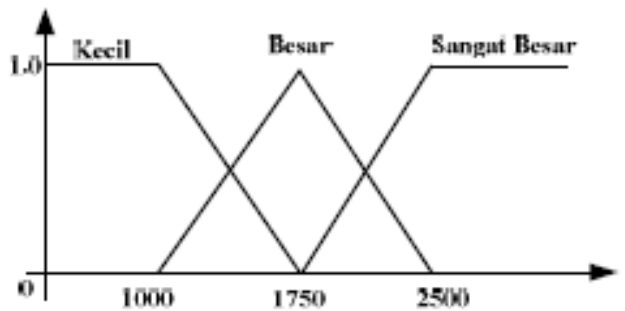

Gambar 3. Fungsi Keanggotaan Variabel Suhu Udara

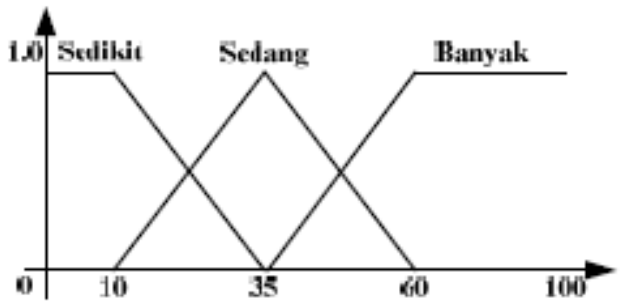

Gambar 4.Fungsi Keanggotaan Variabel Kelembaban Udara
Aplikasi Fungsi Implikasi, Komposisi dan Penegasan (Defuzzyfikasi) Setelah menerima input fungsi keanggotaan dari masing-masing himpunan, langkah selanjutnya adalah mengkombinasikan himpunan-himpunan tersebut menjadi 27 aturan (R). Dengan menggunakan operator AND dalam kombinasi ini, maka penentuan predikat dilakukan dengan mencari nilai ter- kecil dari setiap kombinasi. Agar lebih mudah memahami proses implikasi, komposisi, dan defuzzy, kita asumsikan bahwa:

a) Untuk fungsi keanggotaan Tekanan Udara, himpunan lemah diberi bobot 1, kuat diberi bobot 2, dan sangat kuat diberi bobot 3 .

b) Untuk fungsi keanggotaan Suhu udara: himpunan kecil diberi bobot 1, besar diberi bobot 2, dan sangat besar diberi bobot 3 .

c) Untuk fungsi keanggotaan Kelembaban udara: himpunan sedikit diberi bobot 1 , sedang diberi bobot 2, dan banyak diberi bobot 3

\section{G) Komposisi Aturan}

Tidak seperti penalaran monoton, apabila sistem terdiri-dari beberapa aturan, maka inferensi diperoleh dari kumpulan dan korelasi antar aturan. Ada 3 metode yang digunakan dalam melakukan inferensi sistem fuzzy, yaitu: max, additive dan probabilistik OR (probor).

\section{1) Metode Max (Maximum)}

Pada metode ini, solusi himpunan fuzzy diperoleh dengan cara mengambil nilai maksimum aturan, kemudian menggunakannya untuk memodifikasi daerah fuzzy, dan mengaplikasikannya ke output dengan menggunakan operator OR (union). Jika semua proposisi telah dievaluasi, maka output akan berisi suatu himpunan fuzzy yang merefleksikan konstribusi dari tiap-tiap proposisi. Secara umum dapat dituliskan:

$$
\square \text { sf }\left[\mathrm{x}_{\mathrm{i}}\right] \square \max \left(\square \mathrm{sf}_{\mathrm{s}}\left[\mathrm{x}_{\mathrm{i}}\right], \square \square \mathrm{kf}_{\mathrm{kf}}\left[\mathrm{x}_{\mathrm{i}}\right]\right)
$$

dengan:

$\square_{\mathrm{s}}\left[\mathrm{x}_{\mathrm{i}}\right]=$ nilai keanggotaan solusi fuzzy sampai aturan ke-i;

$$
{ }_{\mathrm{kf}}\left[\mathrm{x}_{\mathrm{i}}\right]=\text { nilai keanggotaan konsekuen fuzzy }
$$
aturan ke-i;

\section{2) Metode Additive (Sum)}

Pada metode ini, solusi himpunan fuzzy diperoleh dengan cara melakukan bounded-sum terhadap semua output daerah fuzzy. Secara umum dituliskan:

$$
\square \text { sf }\left[\mathrm{x}_{\mathrm{i}}\right] \square \min \left(1, \square \mathrm{sf}\left[\mathrm{x}_{\mathrm{i}}\right]+\square \square \mathrm{kf}_{\mathrm{kf}}\left[\mathrm{x}_{\mathrm{i}}\right]\right)
$$

dengan:

$\square_{\mathrm{sf}}\left[\mathrm{x}_{\mathrm{i}}\right]=$ nilai keanggotaan solusi fuzzy sampai aturan ke-i; 
$\square_{\mathrm{kf}}\left[\mathrm{x}_{\mathrm{i}}\right]=$ nilai keanggotaan konsekuen fuzzy aturan ke-i;

\section{3) Metode Probabilistik OR (probor)}

Pada metode ini, solusi himpunan fuzzy diperoleh dengan cara melakukan product terhadap semua output daerah fuzzy. Secara umum dituliskan:

$\square$ sf $\left[\mathrm{x}_{\mathrm{i}}\right] \square\left(\square \mathrm{sf}\left[\mathrm{x}_{\mathrm{i}}\right]+\square \square \mathrm{kf}\left[\mathrm{x}_{\mathrm{i}}\right]\right)-\left(\square \mathrm{sf}_{\mathrm{f}}\left[\mathrm{x}_{\mathrm{i}}\right] * \square \square \mathrm{kf}_{\mathrm{kf}}\left[\mathrm{x}_{\mathrm{i}}\right]\right)$ dengan:

$\square_{\mathrm{sf}}\left[\mathrm{x}_{\mathrm{i}}\right]=$ nilai keanggotaan solusi fuzzy sampai aturan ke-i;

$\square$ kf $\left[\mathrm{x}_{\mathrm{i}}\right]=$ nilai keanggotaan konsekuen fuzzy aturan ke-i;

\section{H) Defuzzifikasi (Defuzzification)}

Defuzzifikasi merupakan sebuah bilangan tunggal,yaitu harga variable masukan dan keluarnya adalah derajat keanggotan dalam suatu fuzzy set dalam antecedent,maka masukan dan keluaran defuzzifikasi adalah sebuah set (dalam hal ini fuzzy set hasil agregasi)dan keluarannya adalah sebuah tunggal untuk diisikan ke sebuah variable keluaran FIS.Ada beberapa jenis versi bilangan tunggal yang dimaksud tersebut .mungkin yang paling populer adalah center of area atau centroid dibawah kurva dari fuzzy set hasil agregasi. transformasi yang menyatakan kembali keluaran dari dominan fuzzy dalam dominan crisp. keluaran fuzzy diperoleh melalui ekaskusi dari beberapa fungsi keanggotaan fuzzy. Terdapat tujuan metode yang dapat digunakan pada proses defuzzifiheight method (Maxmembership principle),dengan mengambil nilai fungsi keanggotaan terbesar dari keluaran fuzzy yang ada untuk dijadikan nilai keluaran dari seluruh fungsi keanggotan keluaran fuzzy yang ada untuk dijadikan nilai defuzzifikasi,centroid (center of grafity)method, mengambil nilai tengah dari seluruh fungsi keanggotan keluaran fuzzy yang ada untuk dijadikan nilai defuzzyfikasi,weighted average method,hanya dapat digunakan untuk keluaran fungsi keanggotan dari beberapa proses fuzzy mempunyai bentuk yang sama,mean-max membership,mempunyai perinsif kerja yang sama dengan metode maxsimum tetapi lokasi dan fungsi keanggotaan maksimum tidak harus unik ,center of sums,mempunyai perinsip kerja yang hampir sama dengan weighted average method tetapi nilai yang dihasilkan merupakan area respektif dari fungi keanggotaan yang ada.

\section{I) Aturan IF-THEN}

Dari data penjelasan parameter-paramater fungsi keanggotan sebagaimana diatas, kemudian dapat dibuat aturan IF-THEN.basis aturan dibentuk dalam
2 bagian yaitu bagian paramatter blok yang digunakan menyimpan nilai-nilai parameter dari satu aturan dan bagian lainnya adalah rulers block yang digunakan untuk menyimpan aturan itu sendiri.

Jumlah aturan IF-THEN yang dihasilkan merrupakan perkalian zikma kemungkinan gejalagejalanya (premis), yang kemudian dikurangi jumlah aturan yang dapat diredukasi.

\section{J) Metode Sugeno}

Menurut fanoeel Thamrin (2012:9) dalam membangun sebuah system fuzzy dikenal beberapa metode penalaran, antara lain: metode Tsukamoto, metode mamdani dan metode sugeno. pada perancangan peramalan cuaca akan digunakan metode Takagi Sugeno.

Fuzzy metode sugeno merupakan metode inferensi fuzzy untuk aturan yang direpresentasikan dalam bentuk $I F$ - THEN, dimana output (konsekuen) sistem tidak berupa himpunan fuzzy, melainkan berupa konstanta atau persamaan linear [KUS-02:98]. Metode ini diperkenalkan oleh Takagi-Sugeno Kang pada tahun 1985. Model Sugeno menggunakan fungsi keanggotaan Singleton yaitu fungsi keanggotaan yang memiliki derajat keanggotaan 1 pada suatu nilai crisp tunggal dan 0 pada nilai crisp yang lain.Untuk Orde 0 dengan rumus :

$$
\begin{aligned}
& \operatorname{IF}(x 1 \text { is a1 })^{\circ}(x 2 \text { is } A 2)^{\circ} \ldots{ }^{\circ}(x n \text { is An }) \\
& \operatorname{THEN~} z=k,
\end{aligned}
$$

dengan Ai adalah himpunan fuzzy ke i sebagai antaseden (alasan), ${ }^{\circ}$ adalah operator fuzzy (AND atau $O R$ ) dan $\mathbf{k}$ merupakan konstanta tegas sebagai konsekuen (kesimpulan).

Sedangkan rumus Orde 1 adalah:

$\operatorname{IF}(x 1 \text { is a1 })^{\circ}(x 2 \text { is A2 })^{\circ} \ldots{ }^{\circ}(x n$ is An $)$

Pada metode Takagi Sugeno ,setiap konsekuen pada aturan yang berbentuk IF-THEN harus di persentasikan dengan suatu himpunan fuzzy dengan fungsi keanggotan monoton.sebagai hasilnya ,output hasil inferensi dari tiap-tiap aturan diberikan (crsip) berdasarkan a-predikat(fire strength).hasil akhirnya diperoleh menggunakan rata-rata terbobot.misal ada 2 variabel input,var $-1\{\mathrm{x}\}$ dan var $-2(\mathrm{y})$ serta 1 variabel output var-3 (z),dimana var-1 terbagi atas 2 himpunan yaitu A1 dan A2 dan var-2 terbagi atas himpunan B1 dan B2.Sedangkan var-3 juga terbagi atas 2himpunan yaitu $\mathrm{C} 1$ dan $\mathrm{C} 2$.Ada 2 aturan yang digunakan yaitu:

[R1] IF ( $\mathrm{x}$ is A1) and (y is B2) THEN ( $\mathrm{z}$ is $\mathrm{c} 1$ )

[R2] IF ( $x$ is $A 2$ ) and (y is $B 1)$ THEN ( $z$ is $C 2$ ). 


\section{K) Matlab}

Menurut Widiarsono (2005:4) Nama Matlab merupakan akronim dari kata Matrix Laboratory. Versi pertama Matlab ditulis pada tahun 1970. Saat itu, Matlab digunakan untuk pelatihan dalam teori matrik, aljabar linier dan analisis numerik. Fungsifungsi Matlab ini digunakan untuk menyelesaikan masalah bagian khusus, yang disebut toolboxes. Toolboxes dapat digunakan untuk bidang pengolahan sinyal, sistem pengaturan, fuzzy logic, numeral network, optimasi, pengolahan citra, dan simulasi yang lain.

Pada matlab terdapat tiga windows yang digunakan dalam operasinya yaitu command windows (layar perintah) dan figure windows (layar gambar), serta Note Pad (sebagai editor program).Command windows (layar perintah) digunakan untuk menjalankan program/ perintah yang dibuat pada layar editor matlab. Pada windows/layar ini anda dapat mengakses perintah maupun komponen pendukung (help file dll) yang ada matlab secara langsung. Salah satu cirri dari command windows ditandai dengan tanda prompt.

\section{METODOLOGI PENELITIAN}

\section{A) Perangkat Keras dan Perangkat Lunak}

Perangkat keras yang dilakukan dalam penelitian ini antara lain:

1) Satu unit Laptop Toshiba intel Pentium Inside

2) Processor Intel Pentium Core i3

3) Memory $2 \mathrm{~GB}$

4) HDD 256 GB

Adapun software yang digunakan dalam penelitian ini adalah: sistem operasi Windous 7, dan aplikasi Matlab r2013a.

\section{B) Metode Perancangan Sistem \\ 1) Blok Diagram Global}

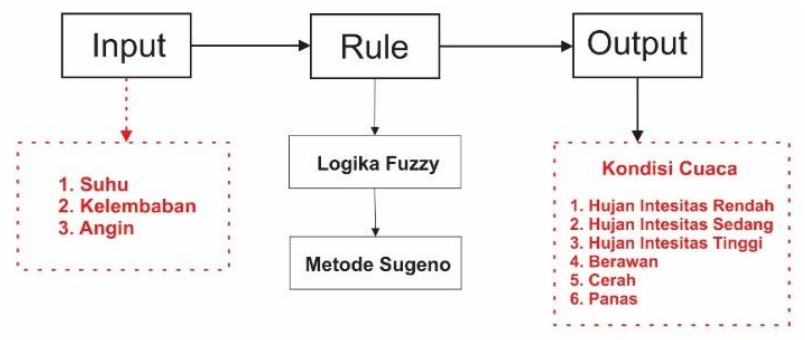

Gambar 5. Blok Diagram Global

\section{2) Prinsip kerja system}

Input berupa hasil penelitian yang dilakukan oleh BMKG dan hasil pengelolahan dari menggunakan metode sugeno. Analisa variable yang mempengaruhi kondisi cuaca adalah sebagai berikut: a) Temperatur atau Suhu

Tabel 2. Keanggotaan atau Domaian untuk Suhu

\begin{tabular}{|l|l|}
\hline Klasifikasi & Suhu \\
\hline Dingin & $\leq 23$ \\
\hline Sedang & $23-26$ \\
\hline Panas & $26-40$ \\
\hline
\end{tabular}

b) Kelembaban

Tabel 3. Keanggotaan atau domain untuk kelembaban

\begin{tabular}{|c|c|}
\hline Klasifikasi & Kelembaban \\
\hline Lembab & $\leq 80$ \\
\hline Sedang & $80-88$ \\
\hline Tidak Lembab & $88-100$ \\
\hline
\end{tabular}

c) Kecepatan Angin

Tabel 4. Keanggotaan atau domain untuk kecepatan angin

\begin{tabular}{|c|c|}
\hline Klasifikasi & Kecepatan Angin \\
\hline Pelan & $\leq 3$ \\
\hline Sedang & $3-6$ \\
\hline Kencang & $6-15$ \\
\hline
\end{tabular}

d) Hujan

Tabel 5. Keanggotaan atau domain untuk Hujan

\begin{tabular}{|l|l|}
\hline Klasifikasi & Curah Hujan \\
\hline Rendah & $\leq 50$ \\
\hline Sedang & $50-100$ \\
\hline Tinggi & $100-200$ \\
\hline
\end{tabular}

e) Cerah

Tabel 6. Keanggotaan atau domain untuk Cerah

\begin{tabular}{|l|c|}
\hline Klasifikasi & Suhu \\
\hline Berawan & $\leq 22$ \\
\hline Cerah & $22-28$ \\
\hline Panas & $28-40$ \\
\hline
\end{tabular}

\section{3) Komponen Logika Fuzzy}

a) Rule Base

Adapun rencana rule base prediksi cuaca khususnya hujan yang akan penulis lakukan dapat dilihat pada tabel berikut ini:

Tabel 7. Rencana Rule Base Prediksi

\begin{tabular}{|c|c|c|c|c|c|}
\hline No & Suhu & Kelembaban & Angin & & \\
\hline 1 & \multirow{3}{*}{ Rendah } & Lembab & Pelan & Sedang & Kencang \\
\hline 2 & & Sedang & Pelan & Sedang & Kencang \\
\hline 3 & & $\begin{array}{l}\text { Tidak } \\
\text { Lembab }\end{array}$ & Pelan & Sedang & Kencang \\
\hline 4 & \multirow{3}{*}{ Sedang } & Lembab & Pelan & Sedang & Kencang \\
\hline 5 & & Sedang & Pelan & Sedang & Kencang \\
\hline 6 & & $\begin{array}{l}\text { Tidak } \\
\text { Lembab }\end{array}$ & Pelan & Sedang & Kencang \\
\hline 7 & \multirow{3}{*}{ Panas } & Lembab & Pelan & Sedang & Kencang \\
\hline 8 & & Sedang & Pelan & Sedang & Kencang \\
\hline 9 & & $\begin{array}{l}\text { Tidak } \\
\text { Lembab }\end{array}$ & Pelan & Sedang & Kencang \\
\hline
\end{tabular}


Tabel 8. Rencana Lanjutan Aturan Prediksi

\begin{tabular}{|c|c|c|c|c|}
\hline \multirow[t]{2}{*}{ No } & \multicolumn{3}{|l|}{ IF } & \multirow[t]{2}{*}{ Then } \\
\hline & Suhu & Kelembaban & Angin & \\
\hline 1 & Dingin & Lembab & Pelan & Hujan Sedang \\
\hline 2 & Dingin & Lembab & Sedang & Hujan Sedang \\
\hline 3 & Dingin & Lembab & Kencang & Hujan Deras \\
\hline 4 & Dingin & Sedang & Pelan & Hujan Sedang \\
\hline 5 & Dingin & Sedang & Sedang & Hujan Sedang \\
\hline 6 & Dingin & Sedang & Kencang & Hujan Deras \\
\hline 7 & Dingin & Tidak Lembab & Pelan & Hujan Rendah \\
\hline 8 & Dingin & Tidak Lembab & Sedang & Hujan Rendah \\
\hline 9 & Dingin & Tidak Lembab & Kencang & Hujan Rendah \\
\hline 10 & \multicolumn{4}{|c|}{ Dan Aturan Prediksi selanjutnya } \\
\hline
\end{tabular}

\section{b) Defuzzyfikasi}

Aplikasi Fungsi Implikasi, Komposisi dan Penegasan (Defuzzyfikasi) Setelah menerima input fungsi keanggotaan dari masing-masing himpunan, langkah selanjutnya adalah mengkombinasikan himpunan-himpunan tersebut menjadi minimal 30 aturan (R). Dengan menggunakan operator AND dalam kombinasi ini, maka penentuan predikat dilakukan dengan mencari nilai terkecil dari setiap kombinasi. Agar lebih mudah memahami proses implikasi, komposisi, dan defuzzy, kita asumsikan bahwa:

$\mu$ Dingin $[s]=\left\{\begin{array}{cc}0 & s \leq 15 \text { atau } s \geq 23 \\ \frac{s-23}{4} & 15 \leq s \leq 23 \\ \frac{23-s}{4} & 25 \leq s \leq 26\end{array}\right.$

$\mu$ sedang $[s]=\left\{\begin{array}{cc}0 & s \leq 23 \text { atau } s \geq 26 \\ \frac{s-23}{4} & 23 \leq s \leq 26 \\ \frac{26-s}{6} & 26 \leq s \leq 32\end{array}\right.$

$\mu$ panas $[s]=\left\{\begin{array}{cc}0 & s \leq 26 \text { atau } s \geq 40 \\ \frac{s-26}{6} & 26 \leq s \leq 40 \\ \frac{40-s}{6} & 26 \leq s \leq 40\end{array}\right.$

Dst

Setelah itu ditentukan rulenya seperti berikut ini

[R1] if suhu "dingin" and tekanan "rendah" and angin "kencang"

Then hujan "intensitas tinggi" $=14,7$

$[R 2]$ if suhu "dingin" and tekanan "rendah" and angin "sedang"

Then hujan "intensitas tinggi" $=22,3$

[R3] if suhu "dingin" and tekanan "rendah" and angin "pelan"

Then hujan "intensitas tinggi" $=22,0$

$[R 4]$ if suhu "dingin" and tekanan "sedang" and angin "kencang"

Then hujan "intensitas Sedang" $=6,0$
[R5] if suhu "dingin" and tekanan "sedang" and angin "sedang" Then hujan "intensitas sedang" $=8,7$

Dst

c) Rencana Rancangan menggunakan tool box Matlab

Dalam melakukan perancangan dengan tool box ini, pertama memilih metode yang digunakan sesuai dengan penelitian yaitu Fuzzy Logic dengan Metode Sugeno. Adapun langkahnya dapat dilihat pada gambar berikut ini:

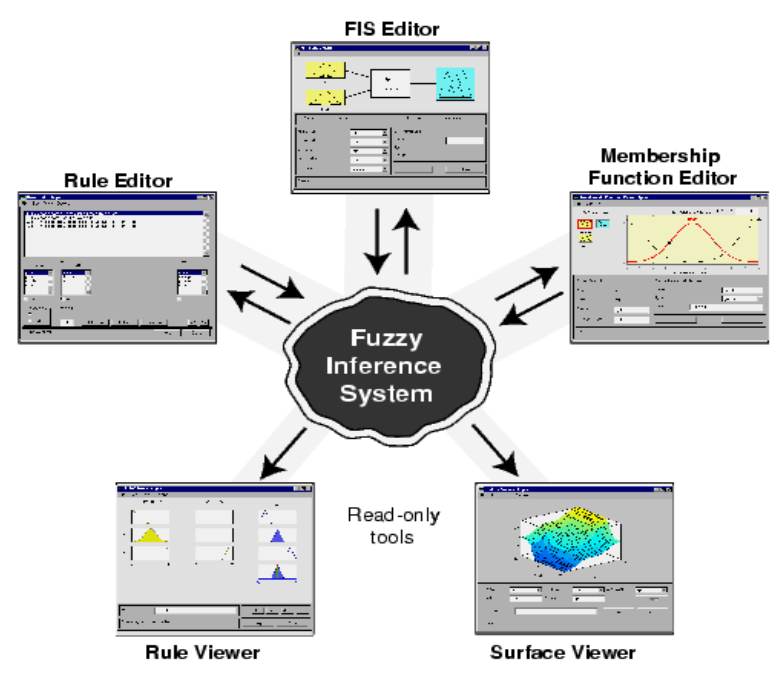

Gambar 6. Fuzzy Inference Sistem

d) Rencana rancangan Aplikasi dengan GUI

Matlab

Rancangan input dan output dari aplikasi peramalan cuaca menggunakan metode sugeno ini dibuat dengan menggunakan tool box bahasa pemrograman matlab r2013a. adapun tampilan input output dapat dilihat pada gambar dibawah ini :

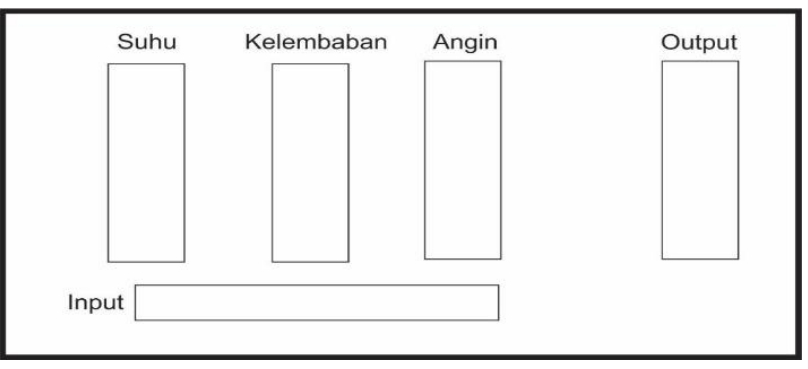

Gambar 7. Rancangan Input dan Output

\section{C) Rancangan Pengujian Sistem}

Black Box pengujian adalah metode pengujian prangkat lunak yang menguji fungsionalitas aplikasi yang bertentangan dengan struktur internal atau kerja (Lihat pengujian white box). Pengetahuan khusus dari kode aplikasi/struktur internal dan pengetahuan 
pemrograman pada umumnya tidak diperlakukan. Uji kasus dibangun disekitar spesifikasi dan persyaratan, yakni, aplikasi apa yang seharusnya dilakukan. Menggunkan deskripsi eksternal perangkat lunak, termasuk spesifikasi, persyaratan dan desain untuk menurunkan uji kasus. Tes ini dapat menjadi fungsional atau nonfungsional meskipun biasanya fungsional. Perancangan uji memilih input yang valid dan tidak valid dan mennetukan output yang benar. Tidak ada pengetahuan struktur internal benda uji itu. (Jogiyanto, 2007:25).

Dari serangkaian penelitian yang penulis lakukan maka penulis membuat sebuah rencana pengujian. Adapun rencana pengujian yang akan penulis lakukan dapat dilihat pada tabel dibawah ini:

Tabel 9. Rencana Pengujian

\begin{tabular}{|l|l|l|l|}
\hline No & Fuzzy Logic & Peramalan & Keterangan \\
\hline 1 & Aktual & & \\
\hline 2 & Peramalan & & \\
\hline \multicolumn{2}{|l|}{ Jumlah Benar (hari) } & \\
\hline Jumlah Benar (hari) & \\
\hline \multicolumn{3}{|c|}{ Keakuratan (\%) } \\
\end{tabular}

\section{PEMBAHASAN}

\section{A) Memulai Logika Fuzzy}

Ketik fuzzy pada lembar command matlab, maka akan muncul tampilan seperti pada gambar berikut:

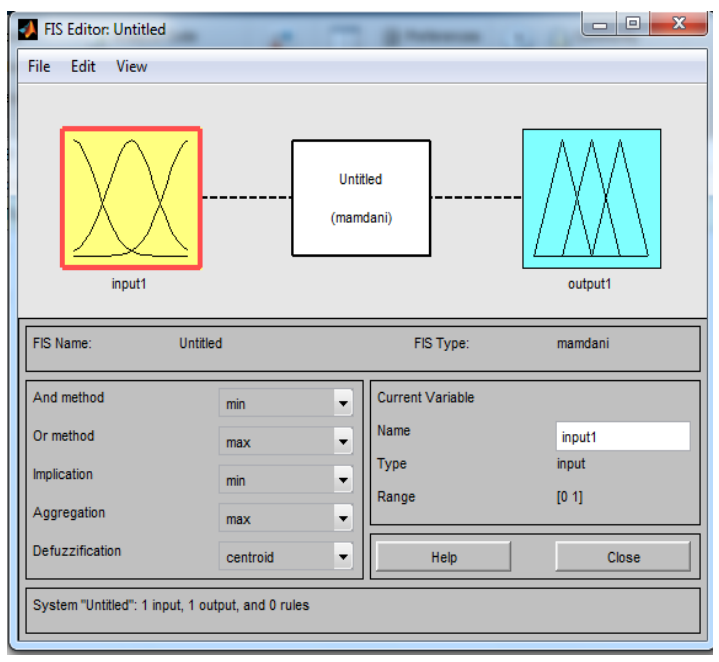

Gambar 8.Tampilan Logika Fuzzy

\section{B) Logika Fuzzy Dengan Metode Sugeno}

Setelah berada pada FIS (Fuzzy Inference System) Editor, selanjut nya pilih file dan new FIS kemudian pilih Metode Sugo. Seperti dapat dilihat pada gambar dibawah ini :

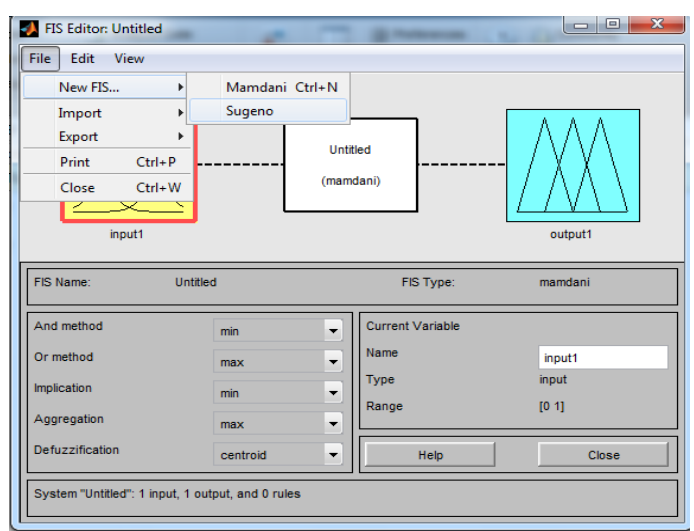

Gambar 9. Tampilan Pilihan Metode Sugeno

Maka setelah itu yang penting atau perlu ditentukan adalah variabel-variabel yang dijadikan input dan output. Dalam hal ini variavel input adalah temperatur, kelembaban, dan angin sedangkan variabel output yaitu prediksi. Sehingga akan menghasilkan seperti pada gambar dibawah ini :

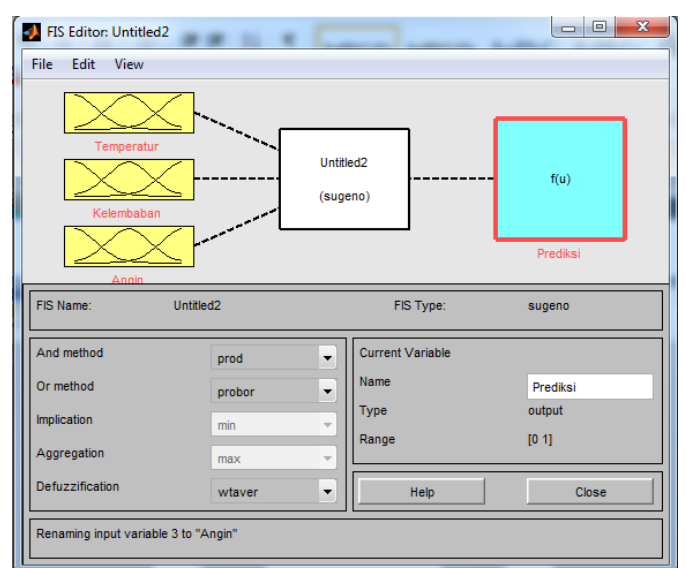

Gambar 10. Tampilan Metode Sugeno

\section{C) Fuzzifikasi}

Fuzzifikasi adalah tahap pemetaan nilai masukan dan keluaran kedalam bentuk himpunan fuzzy. Data masukan berupa himpunan crisp yang akan diubah menjadi himpunan fuzzy berdasarkan range untuk setiap variabel masukannya. Pada proses fuzzifikasi ini terdapat dua hal yang harus diperhatikan yaitu nilai masukan dan keluaran serta fungsi keanggotaan (membership function) yang akan digunakan untuk menentukan nilai fuzzy dari data nilai crisp masukan dan keluaran. Pada proses fuzzifikasi ini digunakan bentuk fungsi keanggotaan gaussian sebagai variabel masukan karena gaussian sesuai apabila digunakan untuk data-data alami seperti data cuaca. Disamping itu juga dipilih fungsi gaussian karena mempunyai tingkat keakurasian tinggi dalam membaca data dibandingkan fungsi lainnya. Proses iterasi dilakukan pada tahap fuzzifikasi, yaitu dengan merubah nilai range dan parameter yang digunakan untuk membangun fungsi keanggotaan, serta dapat juga 
dengan merubah jenis fungsi keanggotaan yang digunakan. Adapun hasil dari fuzzifikasi yang dilakukan untuk masing-masing anggota fuzzy seperti pada gambar berikut ini :

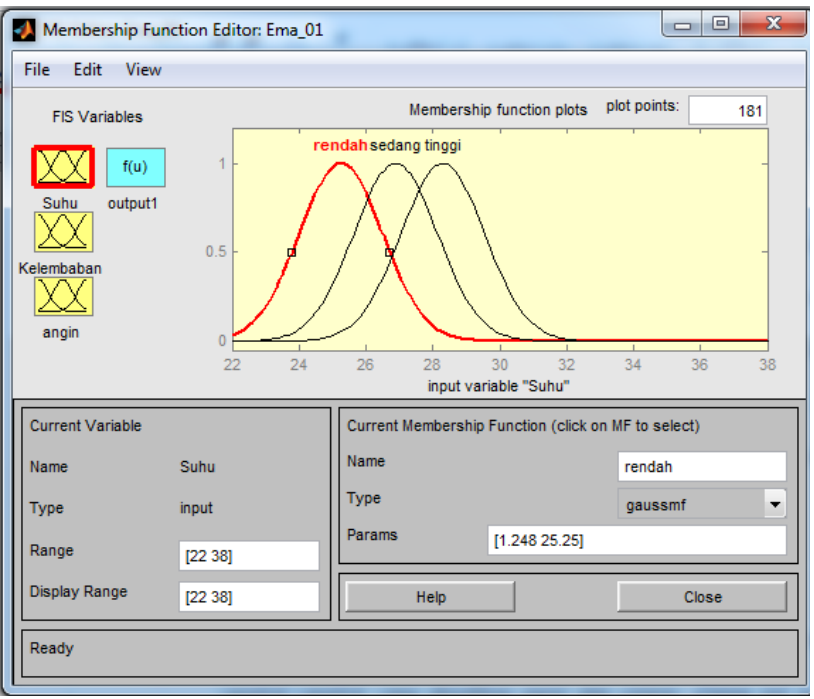

Gambar 11. Tampilan Fungsi Keanggotaan Suhu

Setelah ditentukan fungsi keanggotaan suhu dilanjutkan dengan menentukan fungsi keanggotaan kelembaban, seperti pada gambar berikut ini :

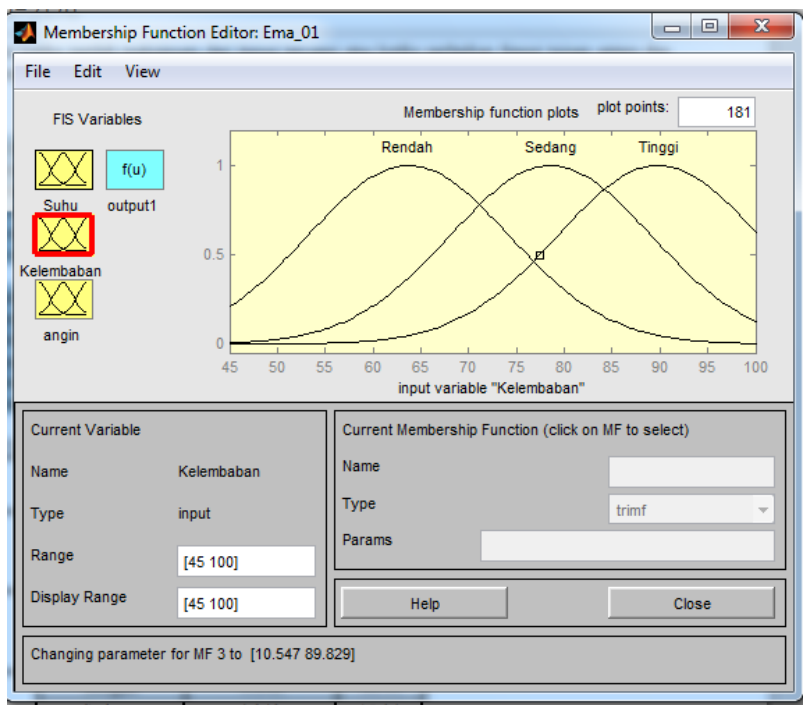

Gambar 12. Tampilan Fungsi Keanggotaan Kelembaban

Setelah ditentukan fungsi keanggotaan kelembaban dilanjutkan dengan menentukan fungsi keanggotaan angin, seperti pada gambar berikut ini:

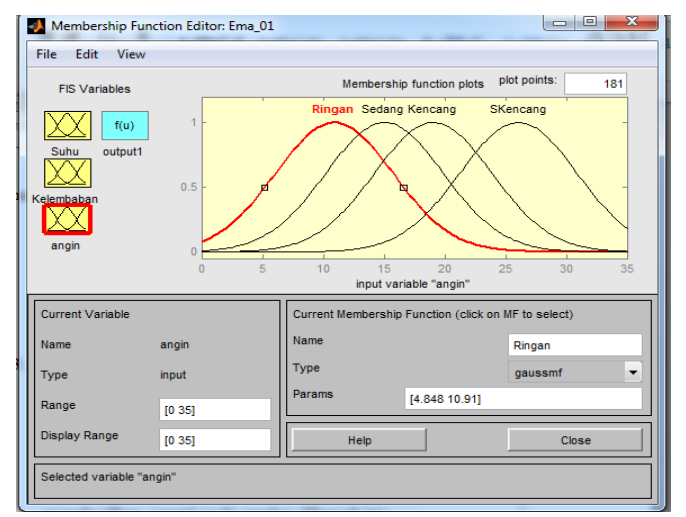

Gambar 13. Tampilan Fungsi Keanggotaan Kelembaban

Setelah semua fungsi keanggotaan yang dijadikan input ditentukan dilanjutkan dengan menentukan fungsi keanggotaan yang dijadikan output, seperti pada gambar berikut ini :

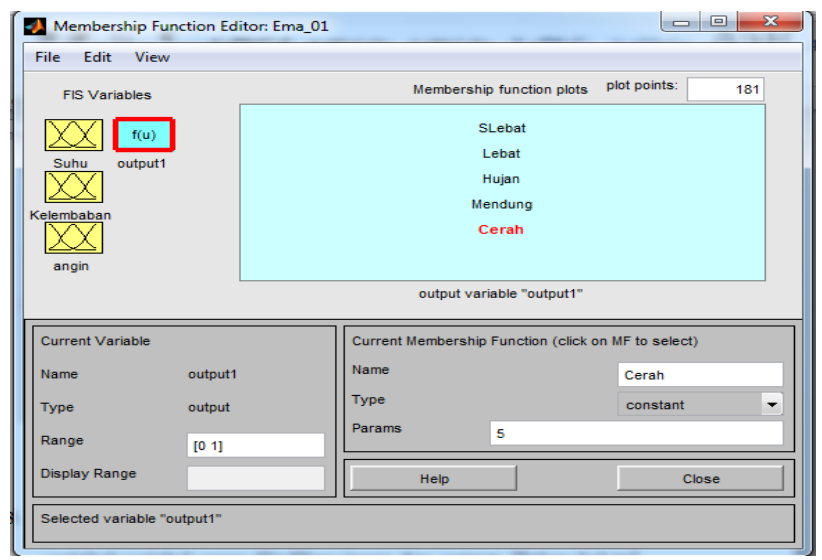

Gambar 14. Tampilan Fungsi Keanggotaan Output

\section{D) Penentuan Rule}

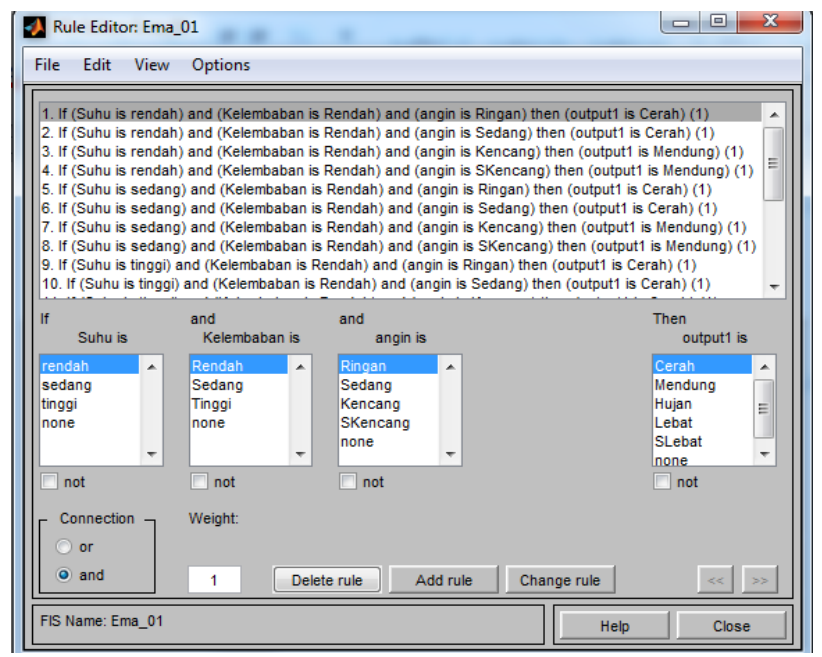

Gambar 15. Tampilan Rule Editor

Rule adalah untuk menentukan kondisi-kondisi input dalam hal ini kondisi suhu, kelembaban dan angin sehingga akan menghasilkan output. 


\section{E) Hasil Pengujian}

Pengujian dilakukan dengan membandingkan prediksi dari pada aplikasi yang dibuat dengan cuara sebenarnya. Adapun tampilan prediksi dari tool box matlab adalah :

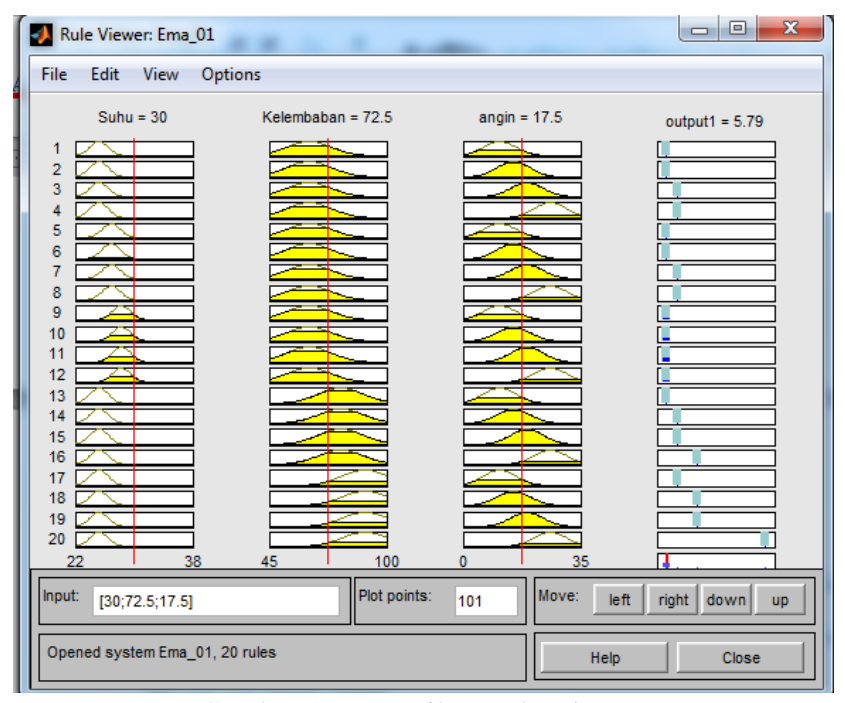

Gambar 16. Tampilan Rule Viewer

Keterangan :

Output $=0-5$ maka Cuaca besok Cerah

Output $=5-20$ maka Cuaca besok Mendung

Output $=20-50$ maka Cuaca besok Hujan

Dari serangkaian penelitian yang penulis lakukan maka penulis membuat sebuah rencana pengujian. Adapun rencana pengujian yang akan penulis lakukan dapat dilihat pada tabel dibawah ini:

Tabel 10. Hasil Pengujian

\begin{tabular}{|l|l|c|c|c|}
\hline \multirow{2}{*}{ No } & \multirow{2}{*}{ Fuzzy Logic } & \multicolumn{2}{|c|}{ Peramalan } & \multirow{2}{*}{ Keterangan } \\
\cline { 3 - 4 } & & Cerah & Hujan & \\
\hline 1 & Aktual & 3 & 4 & \\
\hline 2 & Peramalan & 4 & 3 & \\
\hline \multicolumn{3}{|c|}{ Jumlah Benar (hari) } & \multicolumn{3}{|c|}{ 6 Hari } \\
\hline \multicolumn{3}{|c|}{ Jumlah Salah (hari) } & \multicolumn{3}{|c|}{$75 \%$} \\
\hline \multicolumn{2}{|c|}{ Keakuratan (\%) } & \multicolumn{3}{c}{} \\
\hline
\end{tabular}

Pengujian perancangan peramalan cuaca berbasis logika fuzzy pada kantor Stasiun Meteorologi Fatmawati dengan maksud untuk menguji kelayakan sistem yang dibuat dan untuk mengetahui kelemahan dari sistem yang dibuat sehingga serta dapat dievaluasi atau diperbaiki.

Pengujian dilakukan dengan membuat kuisioner dari aplikasi ini. Kuesioner ini terdiri dari 4 (empat) pertanyaan dengan menggunakan empat pilihan jawaban, kuesioner diserahkan kepada karyawan pada kantor Stasiun Meteorologi Fatmawati Bengkulu. Dari kuisioner tersebut, maka hasil jawaban responden dapat dilihat pada tabel berikut:
Tabel 11. Persentase Hasil Jawaban Responden

\begin{tabular}{|c|c|c|c|c|c|}
\hline No & Pertanyaan & Ya & Tidak & Ragu-Ragu & Total \\
\hline 1 & Pertanyaan 1 & $60 \%$ & $0 \%$ & $40 \%$ & $100 \%$ \\
\hline 2 & Pertanyaan 2 & $60 \%$ & $20 \%$ & $20 \%$ & $100 \%$ \\
\hline 3 & Pertanyaan 3 & $60 \%$ & $0 \%$ & $40 \%$ & $100 \%$ \\
\hline 4 & Pertanyaan 4 & $100 \%$ & $0 \%$ & $0 \%$ & $100 \%$ \\
\hline
\end{tabular}

\section{PENUTUP}

\section{A) Kesimpulan}

Dalam menentukan sebuah peramalan khususnya cuaca yang penting ditentukan adalah fungsi keanggotaan dan rule yang digunakan.

Logika Fuzzy dengan menggunakan metode sugeno sangat baik digunakan dalam peramalan karena tingkat keakuratan diatas $60 \%$.

Semakin banyak variabel-variabel yang dijadikan input maka akan menghasilkan output yang semakin baik (akurat).

\section{B) Saran}

Diharapkan kepada kantor stasiun meteorologi Fatmawati dapat menggunakan aplikasi ini dengan baik untuk menghindari kecelakaan dalam penerbangan.

Dengan keakuratan perkiraan cuaca yang tepat akan memberikan hasil yang lebih baik

\section{DAFTAR PUSTAKA}

Gunawan D, Sudarsono, Wahyuono S, Donatus IA, Purnomo. 2011. Cuaca: Hasil Penelitian, Sifat-sifat dan Penggunaan.Yogyakarta: PPOT UGM

Hasan M. Iqbal. 2002. Pokok-Pokok Materi, Teori Pengambilan Keputusan. Ghalia Indonesia. Jakarta

Meilanitasari, Prita, 2010, Prediksi Cuaca Menggunakan Logika Fuzzy untuk Kelayakan Pelayaran di Tanjung Perak Surabaya, Tugas Akhir Teknik Fisika ITS Surabaya

Raftery, A.E., Gneiting, T., Balabdaoul, F., dan Polakowski, M.,2005, Using Bayesian Model Averaging to Calibrate Forecast Ensembles. Monthly Weather Review, Vol. 133, hal. $1155-117$

Supriyono, Widodo, 2004, Psikologi Belajar. Jakarta: PT Rineka Cipta

Teguh Widiarsono, MT, 2005, Tutorial Praktis Belajar Matlab, Institut Teknologi Bandung 